\title{
Citric Acid-Based Bicarbonate Dialysate Attenuates Aortic Arch Calcification in Maintenance Haemodialysis Patients: An Observational Study
}

\author{
Ken-ichi Akiyama \\ Tokyo Women's Medical University \\ Norio Hanafusa ( $\nabla$ hanafusa.norio@twmu.ac.jp) \\ Tokyo Women's Medical University \\ Yutaka Miura \\ Jichi Medical University \\ Momoko Seki \\ Tokyo Women's Medical University \\ Yoei Miyabe \\ Tokyo Women's Medical University \\ Yuko Iwabuchi \\ Tokyo Women's Medical University

\section{Kazunori Karasawa} \\ Tokyo Women's Medical University \\ Hidekazu Sugiura \\ Saiseikai Kurihashi Hospital

\section{Keiko Uchida} \\ Tokyo Women's Medical University \\ Hiroshi Kawaguchi \\ Joban Hospital \\ Ken Tsuchiya \\ Tokyo Women's Medical University

\section{Makoto Kuro-o} \\ Jichi Medical University \\ Kosaku Nitta \\ Tokyo Women's Medical University

\section{Takahito Moriyama} \\ Tokyo Women's Medical University
}

\section{Research Article}

Keywords: Blood , calciprotein particle (CPP), aortic arch calcification score (AoACS) , warfarin , bisphosphonates

Posted Date: August 3rd, 2021 
DOI: https://doi.org/10.21203/rs.3.rs-754440/v1

License: (c) (i) This work is licensed under a Creative Commons Attribution 4.0 International License. Read Full License 


\section{Abstract}

Introduction: The progression of aortic calcification is associated with mortality in haemodialysis patients. Blood calciprotein particle (CPP) levels are associated with coronary artery calcification, and was reported to be inhibited when using citric acid-based bicarbonate dialysate (CD). Therefore, we examined the effect of $C D$ on the progression of the aortic arch calcification score (AoACS) and blood CPP levels in haemodialysis patients.

Methods: A 12-month retrospective observational study of 262 haemodialysis patients who met the eligibility criteria was conducted at Joban Hospital. Patients taking warfarin or bisphosphonates and those with baseline AoACS of $100 \%$ were excluded. Progression, defined as $\triangle$ AoACS (12 months - baseline) $>0 \%$, was compared between the $C D$ and acetic acid-based bicarbonate dialysate (AD) groups.

Results: The CD group had significantly lower AoACS progression than the AD group $(P=0.037)$. $\triangle \mathrm{CPP}$ and $\triangle$ AoACS were not correlated in the $\operatorname{AD}$ group $\left(R^{2}=0.030, P=0.098\right)$, but were negatively correlated in the $C D$ group $\left(\mathrm{R}^{2}=0.065, P=0.022\right)$. Multivariate logistic analysis showed that the CD (odds ratio [OR] $0.51,95 \%$ confidence interval [Cl] 0.27-0.97, $P=0.042$ ) was significantly associated with the AoACS progression.

Conclusion: CD may suppress the progression of vascular calcification in haemodialysis patients.

\section{Introduction}

The main cause of death in patients with chronic kidney disease (CKD), particularly in those undergoing maintenance haemodialysis, is heart failure and cardiovascular disease due to a high degree of systemic vascular calcification and atherosclerosis. In fact, the mortality rate in patients with CKD is extremely high compared to that for the general population. ${ }^{1}$ The aortic arch calcification score (AoACS), based on a simple chest radiography, correlates well with the aortic arch calcification volume determined by a multidetector computed tomography $(\mathrm{R}=$ $0.635, P<0.001){ }^{2}$ Thus, this is a useful tool as it can be easily evaluated in the clinical setting. Moreover, the presence of aortic ${ }^{3}$ or coronary artery calcification ${ }^{4}$ and progression of aortic arch calcification ${ }^{5,6}$ are reported to be associated with all-cause and cardiovascular mortality. In contrast, clinical studies have reported an association of blood calciprotein particle (CPP) with coronary artery calcification, ${ }^{7}$ atherosclerosis, and markers of inflammation in blood. ${ }^{8}$ CPP in the blood has a physiological effect of transporting calcium-phosphorus, the raw material for teeth and bones; however, in patients with CKD, the amount of primary CPP in the blood is excessive or the dynamics of CPP are abnormally changed, resulting in the formation of secondary CPP, which has a pathological effect. ${ }^{9,10}$

Our in vitro experiments show that citric acid inhibited CPP production as measured by the gel-filtration method. ${ }^{11,}$ 12

We therefore hypothesised that the use of citric acid-based bicarbonate dialysate (CD) would inhibit the progression of vascular calcification by decreasing blood CPP levels in patients with CKD. Here, we aimed to examine the effect of CD on the progression of AoACS and blood CPP levels in patients on maintenance haemodialysis.

\section{Results}

\section{Patient and baseline characteristics}


Figure 1 shows the flow of participants through the study. Of the 262 patients who met the eligibility criteria, 19 patients in the AD group (bisphosphonate: 1, warfarin: 17, AoACS $=100 \%: 1$ ) and 8 patients in the CD group (bisphosphonate: 1, warfarin: 7) were excluded, resulting in the analysis of 130 patients in the AD group and 105 patients in the CD group. Table 1 shows the characteristics at baseline along with the results of comparing the respective characteristics between the two groups. 
Table 1

Baseline (0 month) characteristics of the AD and CD groups $(n=235)$.

\section{Baseline characteristics}

\begin{tabular}{|c|c|c|c|c|}
\hline & All & $A D$ & $C D$ & $\begin{array}{l}\mathrm{P} \text { - } \\
\text { value }\end{array}$ \\
\hline$n$ & 235 & 130 & 105 & \\
\hline Age (years) & $69(60-78)$ & $70(63.8-78.3)$ & $67(57.0-77.0)$ & 0.132 \\
\hline Gender (female), \% & $84(35.7)$ & $44(33.8)$ & $40(38.1)$ & 0.499 \\
\hline Diabetes, \% & 107 (45.5) & $60(46.2)$ & $47(44.8)$ & 0.831 \\
\hline Vintage (year) & $5(3.0-8.3)$ & $5.0(3.0-8.0)$ & $5.3(2.5-8.5)$ & 0.942 \\
\hline $\mathrm{Pi}(\mathrm{mg} / \mathrm{dL})$ & $5.0(4.1-6.1)$ & $4.5(3.9-5.5)$ & $5.6(4.5-6.7)$ & $\begin{array}{l}<.001 \\
0.01\end{array}$ \\
\hline $\mathrm{cCa}(\mathrm{mg} / \mathrm{dL})$ & $9.0(8.5-9.4)$ & $9.0(8.7-9.5)$ & $8.9(8.4-9.4)$ & 0.036 \\
\hline $\begin{array}{l}\text { Ca x Pi product } \\
(\mathrm{mg} / \mathrm{dL})\end{array}$ & $44(37-56)$ & $40(34-50)$ & $50(41-59)$ & $\begin{array}{l}<.001 \\
\end{array}$ \\
\hline iPTH (pg/mL) & $131(64-219)$ & $101(51-178)$ & $171(91-331)$ & $\begin{array}{l}<.001 \\
0.01\end{array}$ \\
\hline $\operatorname{ALP}(\mathrm{U} / \mathrm{L})$ & $226(172-280)$ & $216(175-272)$ & $230(171-289)$ & 0.452 \\
\hline $\mathrm{CRP}(\mathrm{mg} / \mathrm{dL})$ & $0.12(0.05-0.32)$ & $0.09(0.05-0.27)$ & $0.15(0.06-0.47)$ & 0.051 \\
\hline Alb $(g / d L)$ & $3.8(3.6-3.9)$ & $3.8(3.6-4.0)$ & $3.7(3.5-3.9)$ & 0.008 \\
\hline nPCR (g/kg/day) & $0.84(0.74-0.99)$ & $0.83(0.73-0.96)$ & $0.85(0.74-1.02)$ & 0.219 \\
\hline LDL-c (mg/dL) & $86(74-114)$ & $86(73-106)$ & $90(74-117)$ & 0.260 \\
\hline HDL-c (mg/dL) & $47(39-59)$ & $46(39-56)$ & $48(40-62)$ & 0.479 \\
\hline $\mathrm{TG}(\mathrm{mg} / \mathrm{dL})$ & $95(66-135)$ & $90(66-133)$ & $104(67-136)$ & 0.507 \\
\hline $\begin{array}{l}\text { Ca-containing P } \\
\text { binder, \% }\end{array}$ & $168(71.5)$ & $96(73.8)$ & 72 (68.6) & 0.373 \\
\hline AoACS, $\%$ & $19.8(0-37.5)$ & $25.0(0-37.5)$ & $18.8(0-34.4)$ & 0.126 \\
\hline Vitamin D, \% & $163(69.4)$ & $87(66.9)$ & $76(72.4)$ & 0.367 \\
\hline Calcimimetics, \% & $59(25.1)$ & $31(23.8)$ & $28(26.7)$ & 0.620 \\
\hline RAS inhibitors, \% & $34(14.5)$ & $24(18.5)$ & $10(9.5)$ & 0.053 \\
\hline MAP $(\mathrm{mmHg})$ & $106.2 \pm 14.6$ & $104.4 \pm 15.2$ & $108.5 \pm 13.4$ & 0.032 \\
\hline \multicolumn{5}{|c|}{$\begin{array}{l}\text { Data are presented as mean } \pm \text { SD unless stated otherwise. The interquartile range (IQR) is the 25th-75th } \\
\text { percentile. DM, diabetes mellitus; Pi, inorganic phosphorus; cCa, corrected calcium; iPTH, intact parathyroid } \\
\text { hormone; ALP, alkaline phosphatase; CRP, C-reactive protein; Alb, albumin; nPCR, normalised protein catabolic } \\
\text { rate; LDL-c, low density lipoprotein cholesterol; HDL-c, high density lipoprotein cholesterol; TG, triglycerides; } \\
\text { AoACS, aortic arch calcification score; RAS inhibitors, renin-angiotensin system inhibitors; MAP, mean arterial } \\
\text { blood pressure; l, intermittent infusion hemodiafiltration; O, online hemodiafiltration; HD, haemodialysis; Cre, } \\
\text { creatinine; BMI, body mass index; Hb, haemoglobin; FGF23, fibroblast growth factor-23; CPP, calciprotein } \\
\text { particle. }\end{array}$} \\
\hline
\end{tabular}




\begin{tabular}{|c|c|c|c|c|}
\hline \multicolumn{5}{|c|}{ Baseline characteristics } \\
\hline $\begin{array}{l}\text { Kt/Vurea (single- } \\
\text { pool) }\end{array}$ & $1.54 \pm 0.30$ & $1.57(1.39-1.77)$ & $1.45(1.29-1.69)$ & 0.015 \\
\hline Modality (HD, O, I), \% & $\begin{array}{l}171,26,38(73.0,11.0 \\
16.0)\end{array}$ & $\begin{array}{l}118,11,1(90.8,8.5 \\
0.8)\end{array}$ & $\begin{array}{l}85,16,4(81.0,15.2 \\
3.8)\end{array}$ & $\hat{0} .001$ \\
\hline Cre $(\mathrm{mg} / \mathrm{dL})$ & $6.53(4.82-8.22)$ & $6.71(4.49-8.35)$ & $6.40(5.26-8.18)$ & 0.360 \\
\hline $\mathrm{BMI}\left(\mathrm{kg} / \mathrm{m}^{2}\right)$ & $21.9(19.8-24.6)$ & $21.5(19.6-24.4)$ & $22.0(19.9-25.0)$ & 0.368 \\
\hline $\mathrm{Hb}(\mathrm{g} / \mathrm{dL})$ & $11.1(10.4-12.1)$ & $11.0(10.4-11.9)$ & $11.1(10.6-12.3)$ & 0.109 \\
\hline FGF23 (pg/mL) & $3,600(931-12,834)$ & $2,251(587-7,895)$ & $6,377(1,669-17,687)$ & $\hat{0} .001$ \\
\hline CPP (AU) & $\begin{array}{l}63,213(37,364- \\
123,667)\end{array}$ & $\begin{array}{l}54,985(36,825- \\
101,573)\end{array}$ & $\begin{array}{l}71,952(39,582- \\
148,760)\end{array}$ & 0.064 \\
\hline \multicolumn{5}{|c|}{$\begin{array}{l}\text { Data are presented as mean } \pm \text { SD unless stated otherwise. The interquartile range (IQR) is the 25th-75th } \\
\text { percentile. DM, diabetes mellitus; Pi, inorganic phosphorus; cCa, corrected calcium; iPTH, intact parathyroid } \\
\text { hormone } \mathrm{ALP} \text {, alkaline phosphatase; CRP, C-reactive protein; Alb, albumin; nPCR, normalised protein catabolic } \\
\text { rate; LDL-C, low density lipoprotein cholesterol; HDL-c, high density lipoprotein cholesterol; TG, triglycerides; } \\
\text { AoACS, aortic arch calcification score; RAS inhibitors, renin-angiotensin system inhibitors; MAP, mean arterial } \\
\text { blood pressure; l, intermittent infusion hemodiafiltration; O, online hemodiafiltration; HD, haemodialysis; Cre, } \\
\text { creatinine; BMI, body mass index; Hb, haemoglobin; FGF23, fibroblast growth factor-23; CPP, calciprotein } \\
\text { particle. }\end{array}$} \\
\hline
\end{tabular}

\section{Outcomes}

Table 2 shows the characteristics after 12 months, along with the results of comparing the respective characteristics between the two groups. At the end of the 12-month observation period, AoACS had progressed in 71 of the 130 patients in the AD group (54.6\%) and 43 of the 105 patients in the $\mathrm{CD}$ group (41.0\%) $(P=0.037)$ (Table 2). Multivariate logistic analysis showed that the use of CD (OR 0.51 [95\% Cl: $0.27-0.97$ ], $P=0.042$ ) and Age (10 years increase) (OR 2.15 [95\% Cl: 1.20-4.01], $P=0.010$ ) were significantly associated with the progression of AoACS (Table 3). 
Table 2

Characteristics of the AD and CD groups at 12 months $(n=235)$.

\section{$12 \mathrm{M}$ characteristics}

\begin{tabular}{|c|c|c|c|c|}
\hline & All & $A D$ & CD & $\begin{array}{l}\mathrm{P} \text { - } \\
\text { value }\end{array}$ \\
\hline$n$ & 235 & 130 & 105 & \\
\hline $\mathrm{Kt} / \mathrm{V}$ & $1.59 \pm 0.28$ & $1.61 \pm 0.28$ & $1.56 \pm 0.28$ & 0.183 \\
\hline ERI & $37.0(22.1-54.4)$ & $35.1(20.5-53.4)$ & $40.7(25.2-55.1)$ & 0.320 \\
\hline $\mathrm{Pi}(\mathrm{mg} / \mathrm{dL})$ & $5.1(4.2-6.2)$ & $4.8(4.1-5.7)$ & $5.6(4.4-6.9)$ & <. 0.001 \\
\hline $\mathrm{cCa}(\mathrm{mg} / \mathrm{dL})$ & $8.7(8.3-9.2)$ & $8.9(8.5-9.3)$ & $8.6(8.1-9.0)$ & $\begin{array}{l}< \\
0.001\end{array}$ \\
\hline Ca $x$ Pi product & $45(37-56)$ & $43(36-52)$ & $48(37-60)$ & 0.015 \\
\hline iPTH (pg/mL) & $107(58-196)$ & $88(43-166)$ & $143(86-239)$ & $\begin{array}{l}< \\
0.001\end{array}$ \\
\hline Alb (g/dL) & $3.8(3.5-3.9)$ & $3.8(3.6-3.9)$ & $3.7(3.5-3.9)$ & 0.065 \\
\hline nPCR (g/kg/day) & $0.85(0.72-0.97)$ & $0.82(0.71-0.95)$ & $0.87(0.73-1.02)$ & 0.107 \\
\hline Cre (mg/dL) & $6.82(4.74-8.51)$ & $6.93(4.49-8.74)$ & $6.63(5.07-8.38)$ & 0.905 \\
\hline $\mathrm{CRP}(\mathrm{mg} / \mathrm{dL})$ & $0.16(0.06-0.46)$ & $0.13(0.04-0.32)$ & $0.22(0.07-0.70)$ & 0.010 \\
\hline $\mathrm{BMI}\left(\mathrm{kg} / \mathrm{m}^{2}\right)$ & $21.6(19.5-24.5)$ & $21.5(19.3-24.1)$ & $21.9(20.0-25.0)$ & 0.416 \\
\hline $\mathrm{MAP}(\mathrm{mmHg})$ & $106.5 \pm 16.2$ & $104.9 \pm 15.2$ & $108.4 \pm 17.2$ & 0.099 \\
\hline $\begin{array}{l}\text { Modality }(H D, O, I), n \\
(\%)\end{array}$ & $\begin{array}{l}5,27,203(2.1,11.5 \\
86.4)\end{array}$ & $\begin{array}{l}\text { 1, 11, } 118(0.8,8.5 \\
90.7)\end{array}$ & $\begin{array}{l}4,16,85(3.8,15.2 \\
81.0)\end{array}$ & 0.642 \\
\hline FGF23 (pg/mL) & $5,233(1,275-15,086)$ & $3,910(887-11,793)$ & $9,780(3,144-22,940)$ & $\begin{array}{l}< \\
0.001\end{array}$ \\
\hline $\mathrm{CPP}(\mathrm{AU})$ & $\begin{array}{l}87,132(34,537- \\
151,811)\end{array}$ & $\begin{array}{l}82,077(34,239- \\
143,315)\end{array}$ & $\begin{array}{l}88,686(35,243- \\
166,513)\end{array}$ & 0.646 \\
\hline$\triangle$ AoACS & $0(0-12.5)$ & $6.25(0-12.5)$ & $0(0-12.5)$ & 0.110 \\
\hline $\begin{array}{l}\text { AoACS progression, } n \\
(\%)\end{array}$ & $114(49.5)$ & $71(54.6)$ & $43(41.0)$ & 0.037 \\
\hline \multicolumn{5}{|c|}{$\begin{array}{l}\text { Data are presented as mean } \pm \text { SD unless stated otherwise. The interquartile range (IQR) is the 25th-75th } \\
\text { percentile. ERI, erythropoietin resistance index; Pi, inorganic phosphorus; cCa, corrected calcium; iPTH, intact } \\
\text { parathyroid hormone; Alb, albumin; nPCR, normalised protein catabolic rate; Cre, creatinine; CRP, C-reactive } \\
\text { protein; BMI, body mass index; MAP, mean arterial blood pressure; I, intermittent infusion hemodiafiltration; O, } \\
\text { online hemodiafiltration; HD, haemodialysis; FGF23, fibroblast growth factor-23; CPP, calciprotein particle; } \\
\text { AoACS, aortic arch calcification score. }\end{array}$} \\
\hline
\end{tabular}


Table 3

Multivariate logistic regression analysis of univariate differences in background factors ${ }^{a}$.

Univariate analysis

Multivariate analysis

\begin{tabular}{|c|c|c|c|c|c|c|}
\hline Total $n=235$ & OR & $95 \% \mathrm{Cl}$ & P-value & OR & $95 \% \mathrm{Cl}$ & P-value \\
\hline Age (per 10 years increase) & 2.12 & $1.34-3.44$ & 0.017 & 2.15 & $1.20-4.01$ & 0.01 \\
\hline Male (vs. Female) & 1.06 & $0.62-1.81$ & 0.838 & & & \\
\hline DM (vs. non DM) & 1.15 & $0.69-1.93$ & 0.503 & & & \\
\hline Vintage (per 3 years increase) & 1.06 & $0.83-1.34$ & 0.654 & & & \\
\hline Pi (per 2 mg/dL increase) & 0.94 & $0.67-1.32$ & 0.734 & & & \\
\hline cCa (per 0.5 mg/dL increase) & 1.1 & $0.86-1.41$ & 0.432 & & & \\
\hline CaxPi product (per 10 mg/dL increase) & 0.88 & $0.70-1.09$ & 0.237 & & & \\
\hline Intact PTH (per 60 pg/mL increase) & 0.83 & $0.65-1.06$ & 0.137 & & & \\
\hline ALP (per $50 \mathrm{U} / \mathrm{L}$ increase) & 0.79 & $0.63-1.00$ & 0.052 & & & \\
\hline CRP (per 0.12 mg/dL increase) & 0.91 & $0.72-1.16$ & 0.453 & & & \\
\hline Alb (per 0.2 mg/dL increase) & 0.9 & $0.71-1.14$ & 0.395 & & & \\
\hline nPCR (per 0.4 g/kg/day increase) & 0.69 & $0.41-1.13$ & 0.138 & & & \\
\hline LDL-c (per 20 mg/dL increase) & 0.86 & $0.68-1.09$ & 0.204 & & & \\
\hline HDL-c (per 10 mg/dL increase) & 0.86 & $0.68-1.08$ & 0.19 & & & \\
\hline TG (per 10 mg/dL increase) & 0.7 & $0.51-0.94$ & 0.02 & 0.73 & $0.51-1.04$ & 0.082 \\
\hline Ca containing $P$ binder use (vs. No) & 0.75 & $0.42-1.32$ & 0.312 & & & \\
\hline Dialysate : CD (vs. AD) & 0.58 & $0.34-0.97$ & 0.037 & 0.51 & $0.27-0.97$ & 0.042 \\
\hline AoACS (per $10 \%$ increase) & 1.43 & $1.11-1.85$ & 0.005 & 1.27 & $0.93-1.75$ & 0.136 \\
\hline Vitamin D (+ vs. -) & 0.99 & $0.57-1.73$ & 0.983 & & & \\
\hline Calcimimetics (+ vs. -) & 0.95 & $0.52-1.71$ & 0.852 & & & \\
\hline RAS inhibitors (vs. non RAS) & 1.07 & $0.52-2.23$ & 0.851 & & & \\
\hline MAP (per 10 mmHg increase) & 0.87 & $0.67-1.16$ & 0.25 & & & \\
\hline
\end{tabular}

a Background factors: age (10 years increase), intact PTH ( $60 \mathrm{pg} / \mathrm{mL}$ increase), TG $(10 \mathrm{mg} / \mathrm{dL}$ increase),
dialysate: CD (vs AD), and AoACS (10\% increase), with the addition of FGF23 (Log) (pg/mL increase) and CPP
(Log) (AU increase) to these factors, for progression of AoACS.
DM, diabetes mellitus; Pi, inorganic phosphorus; cCa, corrected calcium; iPTH, intact parathyroid hormone; ALP,
alkaline phosphatase; CRP, C-reactive protein; Alb, albumin; $\mathrm{nPCR}$, normalised protein catabolic rate; LDL-C, low
density lipoprotein cholesterol; HDL-c, high density lipoprotein cholesterol; TG, triglycerides; CD, citric acid-
containing dialysate; AD, acetic acid-containing dialysate; AoACS, aortic arch calcification score; RAS inhibitors,
renin-angiotensin system inhibitors; MAP, mean arterial blood pressure; I, intermittent infusion
hemodiafiltration; O, online hemodiafiltration; HD, haemodialysis; Cre, creatinine; BMI, body mass index; Hb,
haemoglobin; FGF23, fibroblast growth factor-23; CPP, calciprotein particle. 


\begin{tabular}{|c|c|c|c|c|c|c|}
\hline \multirow[b]{2}{*}{ Kt/V (per 0.3 increase) } & \multicolumn{2}{|c|}{ Univariate analysis } & & \multicolumn{3}{|c|}{ Multivariate analysis } \\
\hline & 1.17 & $0.84-1.64$ & 0.362 & & & \\
\hline Modality (HD :1, $0: 2,1: 3$ ) & 0.87 & $0.62-1.23$ & 0.438 & & & \\
\hline Cre (per 3 mg/dL increase) & 1.13 & $0.87-1.49$ & 0.352 & & & \\
\hline BMI (per $3 \mathrm{~kg} / \mathrm{m}^{2}$ increase) & 1.02 & $0.78-1.34$ & 0.87 & & & \\
\hline $\mathrm{Hb}$ (per $1 \mathrm{~g} / \mathrm{dL}$ increase) & 0.83 & $0.65-1.07$ & 0.155 & & & \\
\hline FGF23 (Log) (per pg/mL increase) & 1.05 & $0.88-1.26$ & 0.591 & 1.04 & $0.83-1.32$ & 0.713 \\
\hline CPP (Log) (per AU increase) & 1.29 & $0.91-1.85$ & 0.158 & 1.57 & $0.99-2.52$ & 0.056 \\
\hline \multicolumn{7}{|c|}{$\begin{array}{l}\text { a Background factors: age ( } 10 \text { years increase), intact PTH ( } 60 \mathrm{pg} / \mathrm{mL} \text { increase), TG }(10 \mathrm{mg} / \mathrm{dL} \text { increase), } \\
\text { dialysate: CD (vs AD), and AoACS ( } 10 \% \text { increase), with the addition of FGF23 (Log) }(\mathrm{pg} / \mathrm{mL} \text { increase) and CPP } \\
\text { (Log) (AU increase) to these factors, for progression of AoACS. }\end{array}$} \\
\hline \multicolumn{7}{|c|}{$\begin{array}{l}\text { DM, diabetes mellitus; Pi, inorganic phosphorus; cCa, corrected calcium; iPTH, intact parathyroid hormone; ALP, } \\
\text { alkaline phosphatase; CRP, C-reactive protein; Alb, albumin; } \mathrm{NPCR} \text {, normalised protein catabolic rate; LDL-C, low } \\
\text { density lipoprotein cholesterol; HDL-c, high density lipoprotein cholesterol; TG, triglycerides; CD, citric acid- } \\
\text { containing dialysate; AD, acetic acid-containing dialysate; AoACS, aortic arch calcification score; RAS inhibitors, } \\
\text { renin-angiotensin system inhibitors; MAP, mean arterial blood pressure; I, intermittent infusion } \\
\text { hemodiafiltration; O, online hemodiafiltration; HD, haemodialysis; Cre, creatinine; BMI, body mass index; Hb, } \\
\text { haemoglobin; FGF23, fibroblast growth factor-23; CPP, calciprotein particle. }\end{array}$} \\
\hline
\end{tabular}

\section{Subgroup analysis}

Subgroup analysis showed that the factors CRP $0.1 \mathrm{mg} / \mathrm{dL} \geqq 0.1$ (vs. CRP $₫ 0.1 \mathrm{mg} / \mathrm{dL}$ ), AoACS $₫ 19 \%$ (vs. AoACS $\geqq$ $19 \%$ ), cCa $\otimes 9 \mathrm{mg} / \mathrm{dL}$ (vs. cCa $\geqq 9 \mathrm{mg} / \mathrm{dL}$ ), and $\mathrm{iPTH} \otimes 132 \mathrm{pg} / \mathrm{mL}$ (vs. iPTH $\geqq 132 \mathrm{pg} / \mathrm{mL}$ ) were significantly different in the main effect of CD use. Interaction analysis revealed a significant difference only in the factor of AoACS $(P=$ 0.045) (Supplementary Fig.).

\section{Propensity score matching}

Subgroup analysis showed an interaction only in the comparison of the main effect between AoACS less than 19\% and $19 \%$ or more. Based on previous report ${ }^{5}$ and our results, the patients were divided into the following groups according to their baseline AoACS: Grade 0; AoACS = 0\%, grade 1; AoACS $₫ 0 \%$ and $\leqq 25 \%$, grade 2; AoACS $\varangle 25 \%$ and $\leqq 50 \%$, grade 3 ; AoACS $₫ 50 \%$. Of these, the mild to moderate calcification group with grade 2 or less was included in the study, and a comparison using propensity score matching between the two groups of AD and CD was performed. As a result, 15 patients in the AD group and 4 patients in the CD group with AoACS higher than $50 \%$ at baseline were excluded, and 115 patients in the AD group and 101 patients in the CD group were selected (Fig. 1.). After 1:1 propensity score matching, 37 patients were extracted from each group (Fig. 1). We then compared the characteristics at baseline (Table 4) and after 12 months (Table 5). When examining the presence or absence of AoACS progression between the two groups of 115 patients in the AD group and 101 patients in the CD group, which consisted of the mild to moderate calcification group with AoACS of $50 \%$ or less, there was significantly less progression in the CD group, with 66 patients (57.4\%) in the AD group and 42 patients (41.6\%) in the CD group ( $P=$ 0.020) (Table 5). Analysis of the presence of AoACS progression after propensity score matching between the two groups showed that AoACS progressed in 27 of the 37 patients in the AD group (73.0\%) and 14 of the 37 patients in the CD group (37.8\%) $(P=0.002)$ (Table 5). 
Table 4

Baseline (0 month) characteristics of the AD and CD groups before and after propensity score matching $(n=216)$.

\begin{tabular}{|c|c|c|c|c|c|c|}
\hline \multirow{2}{*}{$\begin{array}{l}\begin{array}{l}\text { Baseline } \\
\text { characteristics }\end{array} \\
\text { Total } n=216\end{array}$} & \multicolumn{3}{|c|}{ Before matching } & \multicolumn{3}{|l|}{ After matching } \\
\hline & $A D$ & CD & $\begin{array}{l}\mathrm{P}- \\
\text { value }\end{array}$ & $A D$ & $C D$ & $\begin{array}{l}\mathrm{P} \text { - } \\
\text { value }\end{array}$ \\
\hline$n$ & 115 & 101 & & 37 & 37 & \\
\hline Age (years) & $\begin{array}{l}69(62.0- \\
78.0)\end{array}$ & $67(56.5-77.0)$ & 0.270 & $71(59.5-81.5)$ & $\begin{array}{l}70(58.5- \\
80.5)\end{array}$ & 0.626 \\
\hline Gender (female), \% & 31.3 & 35.6 & 0.499 & 37.8 & 32.4 & 0.807 \\
\hline $\mathrm{DM}, \%$ & 44.3 & 44.6 & 0.975 & 45.9 & 48.6 & 0.815 \\
\hline Dialysis vintage (year) & $5.0(3-8.0)$ & $5.3(2.6-8.4)$ & 0.747 & $5.0(3-8.5)$ & $5.3(3.7-8.3)$ & 0.943 \\
\hline $\mathrm{Pi}(\mathrm{mg} / \mathrm{dL})$ & $\begin{array}{l}4.5(3.9- \\
5.5)\end{array}$ & $5.5(4.5-6.7)$ & $<.001$ & $4.8(4.1-5.4)$ & $4.9(4.0-6.0)$ & 0.832 \\
\hline $\mathrm{cCa}(\mathrm{mg} / \mathrm{dL})$ & $\begin{array}{l}9.0(8.7- \\
9.5)\end{array}$ & $8.9(8.4-9.4)$ & 0.054 & $8.9(8.7-9.4)$ & $9.1(8.7-9.6)$ & 0.357 \\
\hline $\begin{array}{l}\text { Ca } x \text { Pi product } \\
(\mathrm{mg} / \mathrm{dL})\end{array}$ & $41(35-50)$ & $50(40-58)$ & $<.001$ & $42(37-51)$ & $43(36-56)$ & 0.709 \\
\hline iPTH (pg/mL) & $\begin{array}{l}102(49- \\
179)\end{array}$ & $169(88-323)$ & $<.001$ & $145(66-212)$ & $94(64-195)$ & 0.372 \\
\hline ALP (U/L) & $\begin{array}{l}214(171- \\
267)\end{array}$ & $229(167-286)$ & 0.310 & $216(172-269)$ & $\begin{array}{l}245(186- \\
289)\end{array}$ & 0.399 \\
\hline CRP (mg/dL) & $\begin{array}{l}0.09(0.05- \\
0.27)\end{array}$ & $\begin{array}{l}0.15(0.06- \\
0.44)\end{array}$ & 0.092 & $\begin{array}{l}0.13(0.07- \\
0.28)\end{array}$ & $\begin{array}{l}0.20(0.06- \\
0.62)\end{array}$ & 0.337 \\
\hline Alb $(g / d L)$ & $3.8(3.6-4.0)$ & $3.7(3.5-3.9)$ & 0.005 & $3.8(3.7-4.0)$ & $3.7(3.6-4.0)$ & 0.377 \\
\hline nPCR (g/kg/day) & $\begin{array}{l}0.83(0.73- \\
0.96)\end{array}$ & $\begin{array}{l}0.85(0.73- \\
1.00)\end{array}$ & 0.427 & $0.84 \pm 0.35$ & $0.84 \pm 0.35$ & 0.920 \\
\hline LDL-c (mg/dL) & $85(73-107)$ & $90(74-116)$ & 0.316 & $85(76-106)$ & $98(74-114)$ & 0.713 \\
\hline HDL-c (mg/dL) & $46(39-56)$ & $48(40-62)$ & 0.393 & $48 \pm 28$ & $49 \pm 31$ & 0.741 \\
\hline $\mathrm{TG}(\mathrm{mg} / \mathrm{dL})$ & $91(69-137)$ & $101(65-136)$ & 0.756 & $92(73-136)$ & $105(72-143)$ & 0.673 \\
\hline $\begin{array}{l}\text { Ca-containing } \mathrm{P} \text { binder, } \\
\%\end{array}$ & 72.2 & 68.3 & 0.535 & 73 & 73 & 1 \\
\hline AoACS, \% & $\begin{array}{l}18.8(0- \\
31.3)\end{array}$ & $18.8(0-31.3)$ & 0.270 & $\begin{array}{l}25.0(12.5- \\
31.3)\end{array}$ & $25.0(0-37.5)$ & 0.960 \\
\hline
\end{tabular}

Data are presented as mean \pm SD unless stated otherwise. The interquartile range (IQR) is the 25th-75th percentile. DM, diabetes mellitus; $\mathrm{Pi}$, inorganic phosphorus; $\mathrm{cCa}$, corrected calcium; iPTH, intact parathyroid hormone; ALP, alkaline phosphatase; CRP, C-reactive protein; Alb, albumin; nPCR, normalised protein catabolic rate; LDL-c, low density lipoprotein cholesterol; HDL-C, high density lipoprotein cholesterol; TG, triglycerides; AoACS, aortic arch calcification score; RAS inhibitors, renin-angiotensin system inhibitors; MAP, mean arterial blood pressure; I, intermittent infusion hemodiafiltration; $\mathrm{O}$, online hemodiafiltration; HD, haemodialysis; Cre, creatinine; BMI, body mass index; Hb, haemoglobin; FGF23, fibroblast growth factor-23; CPP, calciprotein particle. 


\begin{tabular}{|c|c|c|c|c|c|c|}
\hline \multirow{2}{*}{$\begin{array}{l}\text { Baseline } \\
\text { characteristics } \\
\text { Vitamin D, \% }\end{array}$} & \multicolumn{3}{|c|}{ Before matching } & \multicolumn{3}{|l|}{ After matching } \\
\hline & 69.6 & 75.2 & 0.352 & 64.9 & 70.3 & 0.619 \\
\hline Calcimimetics, \% & 33 & 38.6 & 0.393 & 35.1 & 29.7 & 0.619 \\
\hline RAS inhibitors, \% & 18.3 & 8.9 & 0.047 & 8.1 & 10.8 & 0.691 \\
\hline MAP (mmHg) & $105 \pm 15$ & $108 \pm 13$ & 0.074 & $102 \pm 31$ & $105 \pm 23$ & 0.390 \\
\hline Kt/Vurea (single-pool) & $\begin{array}{l}1.56(1.36- \\
1.79)\end{array}$ & $\begin{array}{l}1.44(1.27- \\
1.66)\end{array}$ & 0.018 & $1.59 \pm 0.48$ & $1.54 \pm 0.52$ & 0.454 \\
\hline $\begin{array}{l}\text { Intermittent/online/HD, } \\
\%\end{array}$ & 7.8/9.6/82.6 & 25.7/13.9/60.4 & $\hat{0} .001$ & 13.5/16.2/70.3 & $2.4 / 13.5 / 62.2$ & 0.492 \\
\hline Cre (mg/dL) & $\begin{array}{l}6.66(4.67- \\
8.41)\end{array}$ & $\begin{array}{l}6.40(5.26- \\
8.18)\end{array}$ & 0.392 & $\begin{array}{l}6.60(4.45- \\
8.43)\end{array}$ & $\begin{array}{l}6.44(4.82- \\
8.17)\end{array}$ & 0.541 \\
\hline $\mathrm{BMI}\left(\mathrm{kg} / \mathrm{m}^{2}\right)$ & $\begin{array}{l}21.8(19.6- \\
24.6)\end{array}$ & $\begin{array}{l}22.2(19.9- \\
25.1)\end{array}$ & 0.589 & $22.9 \pm 8.3$ & $23.0 \pm 8.4$ & 0.891 \\
\hline $\mathrm{Hb}(\mathrm{g} / \mathrm{dL})$ & $\begin{array}{l}11.0(10.4- \\
11.9)\end{array}$ & $\begin{array}{l}11.1(10.6- \\
12.3)\end{array}$ & 0.119 & $11.0 \pm 2.6$ & $11.0 \pm 2.1$ & 1 \\
\hline FGF23 (pg/mL) & $\begin{array}{l}2,016(556- \\
6,141)\end{array}$ & $\begin{array}{l}6,377(1,669- \\
19,232)\end{array}$ & $\hat{0} .001$ & $\begin{array}{l}3,496(1,651- \\
12,776)\end{array}$ & $\begin{array}{l}3,600(931- \\
10,328)\end{array}$ & 0.611 \\
\hline CPP (AU) & $\begin{array}{l}54,410 \\
(34,062- \\
92,095)\end{array}$ & $\begin{array}{l}71,952 \\
(39,582- \\
170,928)\end{array}$ & 0.032 & $\begin{array}{l}70,013 \\
(40,631- \\
123,120)\end{array}$ & $\begin{array}{l}70,491 \\
(26,649- \\
129,328)\end{array}$ & 0.854 \\
\hline \multicolumn{7}{|c|}{$\begin{array}{l}\text { Data are presented as mean } \pm \text { SD unless stated otherwise. The interquartile range (IQR) is the 25th-75th } \\
\text { percentile. DM, diabetes mellitus; Pi, inorganic phosphorus; cCa, corrected calcium; iPTH, intact parathyroid } \\
\text { hormone; ALP, alkaline phosphatase; CRP, C-reactive protein; Alb, albumin; } \mathrm{HPCR} \text {, normalised protein catabolic } \\
\text { rate; LDL-c, low density lipoprotein cholesterol; HDL-C, high density lipoprotein cholesterol; TG, triglycerides; } \\
\text { AoACS, aortic arch calcification score; RAS inhibitors, renin-angiotensin system inhibitors; MAP, mean arterial } \\
\text { blood pressure; I, intermittent infusion hemodiafiltration; O, online hemodiafiltration; HD, haemodialysis; Cre, } \\
\text { creatinine; BMI, body mass index; Hb, haemoglobin; FGF23, fibroblast growth factor-23; CPP, calciprotein } \\
\text { particle. }\end{array}$} \\
\hline
\end{tabular}


Table 5

Characteristics of the AD and CD groups at 12 months before and after propensity score matching for background factors at baseline $(n=216)$.

\begin{tabular}{|c|c|c|c|c|c|}
\hline \multicolumn{3}{|c|}{ Before baseline matching } & \multicolumn{3}{|c|}{ After baseline matching } \\
\hline$A D$ & CD & $\begin{array}{l}\mathrm{P} \text { - } \\
\text { value }\end{array}$ & $A D$ & CD & $\begin{array}{l}\mathrm{P}- \\
\text { value }\end{array}$ \\
\hline 115 & 101 & & 37 & 37 & \\
\hline $1.61 \pm 0.27$ & $1.54 \pm 0.27$ & 0.097 & $1.60 \pm 0.25$ & $1.57 \pm 0.23$ & 0.455 \\
\hline $33.6(20.4-49.7)$ & $40.8(26.8-55.1)$ & 0.099 & $33.2(16.7-427)$ & $38.8(20.8-52.3)$ & 0.279 \\
\hline $4.8(4.1-5.8)$ & $5.6(4.4-6.9)$ & 0.001 & $5.0 \pm 1.1$ & $5.8 \pm 1.8$ & 0.030 \\
\hline $9.1(8.8-9.6)$ & $9.0(8.6-9.5)$ & 0.042 & $9.3(8.9-9.7)$ & $9.0(8.8-9.4)$ & 0.141 \\
\hline $43(36-52)$ & $48(37-60)$ & 0.024 & $45.0 \pm 10.9$ & $51.1 \pm 17.2$ & 0.074 \\
\hline $86(37-165)$ & $146(88-239)$ & $\dot{0} 001$ & $103(47-183)$ & $126(86-207)$ & 0.224 \\
\hline $3.8(3.6-3.9)$ & $3.7(3.5-3.9)$ & 0.023 & $3.7 \pm 0.38$ & $3.7 \pm 0.32$ & 0.551 \\
\hline $0.84 \pm 0.17$ & $0.87 \pm 0.20$ & 0.161 & $0.84 \pm 0.19$ & $0.90 \pm 0.19$ & 0.209 \\
\hline $6.94(4.52-8.76)$ & $6.63(4.95-8.38)$ & 0.880 & $6.41(4.71-9.11)$ & $6.99(4.79-8.31)$ & 0.918 \\
\hline $0.13(0.04-0.32)$ & $0.25(0.07-0.93)$ & 0.003 & $0.23(0.06-0.33)$ & $0.33(0.07-1.46)$ & 0.116 \\
\hline $21.6(19.4-24.4)$ & $22.0(19.9-25.1)$ & 0.638 & $22.6 \pm 4.4$ & $22.7 \pm 4.3$ & 0.958 \\
\hline $104(95-116)$ & $110(99-120)$ & 0.070 & $107 \pm 14$ & $105 \pm 19$ & 0.569 \\
\hline $\begin{array}{l}103,11,1(89.6,9.6 \\
0.8)\end{array}$ & $\begin{array}{l}83,14,4(82.2,13.9 \\
3.9)\end{array}$ & 0.181 & $30,6,1(81,16,3)$ & $\begin{array}{l}31,5,1(83.8,13.5 \\
2.7)\end{array}$ & 0.947 \\
\hline $4,260(880-11,780)$ & $\begin{array}{l}9,780(30,010- \\
22,940)\end{array}$ & 0.001 & $5,091(893-15,922)$ & $\begin{array}{l}4,515(1,547- \\
13,807)\end{array}$ & 0.948 \\
\hline $\begin{array}{l}8,9145(36,918- \\
151,811)\end{array}$ & $\begin{array}{l}79,281(32,571- \\
166,513)\end{array}$ & 0.894 & $\begin{array}{l}79,766(31,599- \\
158,128)\end{array}$ & $\begin{array}{l}77,594(38,146- \\
136,009)\end{array}$ & 0.620 \\
\hline $66(57.4)$ & $42(41.6)$ & 0.020 & $27(73.0)$ & $14(37.8)$ & 0.002 \\
\hline $6.25(0-12.5)$ & $0(0-12.5)$ & 0.052 & $6.25(0-12.5)$ & $0(0-12.5)$ & 0.055 \\
\hline $\begin{array}{l}\text { Data are presented as } \\
\text { percentile. ERI, erythrc } \\
\text { parathyroid hormone; } \\
\text { protein; BMI, body ma } \\
\text { online hemodiafiltrati } \\
\text { AoACS, aortic arch ca }\end{array}$ & $\begin{array}{l}\text { ean } \pm \text { SD unless stat } \\
\text { ietin resistance index } \\
\text { b, albumin; } n P C R \text {, nor } \\
\text { index; MAP, mean ar } \\
\text { HD, haemodialysis; } \\
\text { fication score. }\end{array}$ & $\begin{array}{l}\text { therw } \\
\text { inoro } \\
\text { lised } \\
\text { a bloc } \\
\text { 23, fib }\end{array}$ & $\begin{array}{l}\text { The interquartile ran } \\
\text { ic phosphorus; cCa, } \\
\text { tein catabolic rate; } \mathrm{Cr} \\
\text { ressure; I, intermitten } \\
\text { last growth factor- } 23\end{array}$ & $\begin{array}{l}\text { (IQR) is the } 25 \text { th }-75 \\
\text { ected calcium; iPTH, } \\
\text { reatinine; CRP, C-reac } \\
\text { fusion hemodiafiltra } \\
\text { PP, calciprotein parti }\end{array}$ & \\
\hline
\end{tabular}

Although the conventional level of statistical significance was not reached, the simple subtraction 12-month AoACS - baseline [0-month] AoACS (\%) tended to be lower in the CD group, both before (AD: 6.25 [0-12.5] \% vs. CD: 0 [0$12.5] \%, P=0.052)$ and after (AD: $6.25[0-12.5] \%$ vs. CD: $0[0-12.5] \%, P=0.055)$ propensity score matching (Table 5). Unexpectedly, the blood phosphorus levels were significantly higher in the CD group at 12 months, both before $(P=0.001)$ and after $(P=0.030)$ propensity score matching (Table 5$)$. 


\section{Relationship between AoACS and blood CPP (total $\mathbf{n}=235$ )}

Correlation coefficients for $\triangle \mathrm{CPP}$ and $\triangle \mathrm{AoACS}$ were analyzed for 130 patients in the AD group and 105 patients in the $C D$ group after excluding patients with AoACS $=100 \%$, warfarin, and bisphosphonate use. The correlation between $\triangle \mathrm{CPP}$ and $\triangle$ AoACS was examined in the $\mathrm{AD}\left(\mathrm{R}^{2}=0.030, P=0.079\right)$ and $\mathrm{CD}$ groups $\left(\mathrm{R}^{2}=0.030, P=0.079\right)$, respectively, but there was no correlation in both groups (Fig. 2a, b).

\section{Relationship between blood FGF23 and AoACS and blood CPP (total $n=235$ )}

There was no correlation between $\triangle \mathrm{FGF} 23$ and $\triangle$ AoACS in either the $\mathrm{AD}\left(\mathrm{R}^{2} \llbracket 0.001, P=0.932\right)$ (Fig. $\left.2 \mathrm{C}\right)$ or $\mathrm{CD}$ groups $\left(R^{2}=0.012, P=0.321\right)$ (Fig. $\left.2 d\right)$. In contrast, there was a weak but significant positive correlation between blood $\triangle$ FGF23 and $\triangle \mathrm{CPP}$ in both the $\mathrm{AD}\left(\mathrm{R}^{2}=0.216, P \otimes 0.001\right)($ Fig. $2 \mathrm{e})$, and CD groups $\left(\mathrm{R}^{2}=0.153, P \otimes 0.001\right)$ (Fig. 2f).

\section{Relationship between AoACS and blood CPP (total $n=216$ )}

Correlation coefficients for $\triangle \mathrm{CPP}$ and $\triangle \mathrm{AoACS}$ were analyzed for 115 patients in the AD group and 101 patients in the CD group after excluding patients with AoACS $>50 \%$, warfarin, and bisphosphonate use. The AD group showed a non-significant but a weak positive correlation between $\triangle$ AoACS and $\triangle \mathrm{CPP}\left(\mathrm{R}^{2}=0.030, P=0.098\right)$ (Fig. 3a), while the $C D$ group showed a significant negative correlation between these factors $\left(R^{2}=0.065, P=0.022\right)($ Fig. $3 b)$.

\section{Relationship between blood FGF23 and AoACS and blood CPP (total $n=216$ )}

There was no significant association between $\triangle$ FGF23 and $\triangle$ AoACS in blood in either the $\operatorname{AD}\left(R^{2}<0.001 P=0.893\right)$ (Fig. 3c) or CD groups $\left(\mathrm{R}^{2}=0.001, P=0.7315\right)$ (Fig. 3d). In contrast, there was a significant positive correlation between blood $\triangle$ FGF23 and $\triangle$ CPP in both the $A D\left(R^{2}=0.174, P<0.001\right)$ (Fig. 3e), and CD groups $\left(R^{2}=0.115, P=\right.$ 0.001) (Fig. 3f).

\section{Discussion}

In this study, we examined the effect of CD on the progression of the AoACS (AoACS progression as defined by $\triangle \mathrm{AoACS}>0 \%$ ) and blood CPP levels and showed that the use of CD attenuated blood CPP and suppressed the progression of vascular calcification in patients on maintenance haemodialysis.

The physiological role of primary CPP is to transport calcium-phosphorus, a raw material for teeth and bone, to these tissues, without it precipitating in soft tissue. ${ }^{9,10}$ The uremic environment may cause transformation of primary CPP to secondary CPP to be phagocytosed by the macrophages in the vessel wall, which may contribute to atherosclerosis ${ }^{13}$ and vascular calcification in the tunica media. ${ }^{14}$ In fact, it has been reported that CPP levels measured by the gel-filtration method were positively correlated with coronary plaque assessed by intravascular ultrasound, even after adjusting for a number of confounding factors. ${ }^{15}$ Due to this positive association between blood CPP and arterial calcification in CKD, the Ca-chelating effect of citric acid in CD may have inhibited the formation of blood secondary CPP, which in turn inhibited the progression of vascular calcification. In the present study, $\triangle \mathrm{CPP}$ and $\triangle$ AoACS were negatively correlated in the CD group (Fig. 2b), suggesting that citric acid may have 
inhibited the formation of primary to secondary CPP and promoted the incorporation of primary CPP into bone. There is a lack of consensus on whether FGF23 in blood is associated with vascular calcification in CKD patients. 16, 17 In our study, we did not find any significant association between blood FGF23 and AoACS (Fig. 2c, 2d). From the viewpoint that FGF23 is a phosphaturic hormone, in the early stage of CKD, when renal function is preserved, FGF23 acts on the kidney to produce Pi-diuretic effect and inhibition of vitamin D activation, and thus FGF23 is thought to have a protective effect against vascular calcification. However, in CKD patients undergoing maintenance hemodialysis, renal function is abolished, so the effects of Pi-diuresis and vitamin D inhibition in the kidney are not obtained and are not associated with vascular calcification. In the present study, we did find a weak but significant positive correlation between $\triangle$ CPP and $\triangle F G F 23$ in blood (Fig. 2e, 2f). FGF23 in blood is probably produced by osteoblasts and osteocytes upon primary CPP stimulation, while secondary CPP acts on vascular calcification because it cannot pass through bone sinuses due to its large size. ${ }^{12,18}$ As compared to $A D, C D$ has the potential to improve prognosis in patients on maintenance haemodialysis. ${ }^{19}$ This may be due to the inhibition of secondary CPP production by citrate. ${ }^{12}$ CPP is thought to induce FGF23 secretion, ${ }^{12,18}$ and FGF23 is associated with mortality and cardiovascular disease in patients on maintenance haemodialysis. ${ }^{20} \mathrm{An}$ in vivo rat study has reported that recombinant FGF23 directly causes cardiac hypertrophy and that there was a significant positive correlation between blood FGF23 and cardiac hypertrophy assessed by echocardiography in patients with CKD. ${ }^{21}$ Similar to our findings, the use of CD has previously been reported to inhibit CPP ripening, as indicated by T50 (T50 is $1 / 2$ of the time it takes for the turbidity of primary CPP in the blood to rapidly increase to secondary CPP). ${ }^{22,23}$ Based on previous reports, primary CPP excess, in other words, excess of both Pi and Ca in the blood is thought to be associated with worse prognosis via FGF23 secretion, and secondary CPP is thought to be associated with worse prognosis via vascular calcification.

Another reason for the greater efficacy of $C D$ than $A D$ in suppressing arterial calcification may be related to the following: An ex vivo model showed that citric acid, at concentrations of $733 \mu \mathrm{mol} / \mathrm{L}$ or higher, inhibited rat aortic ring calcification. ${ }^{24}$ The post-dialysis blood citrate concentration in haemodialysis patients using CD has been reported to be $771.6 \pm 184.3 \mu \mathrm{mol} / \mathrm{L}$, which was approximately five times higher than that of $A D .{ }^{24}$ Moreover, bicarbonate promoted rat aortic ring calcification in a concentration-dependent manner. ${ }^{24}$ The use of $A D$ in haemodialysis patients was reported to result in a higher post-dialysis blood bicarbonate concentrations and lower citric acid concentrations than those obtained with CD. ${ }^{24}$ Moreover, it was reported that no excess bicarbonate correction was observed after dialysis with $C D .{ }^{25}$ Switching from AD to CD was reported to significantly reduce malondialdehyde-modified LDL(MDA-LDL) (an indicator of lipid oxidation) and pentosidine (an indicator of glycoxidation) level in the blood. ${ }^{26}$ Therefore, it is likely that CD inhibits lipid oxidation, which is associated with coronary artery calcification, ${ }^{27}$ as well as glycation, which causes atherosclerosis ${ }^{28}$ in patients on maintenance haemodialysis, thereby exerting anti-atherosclerotic effects. In subgroup analysis, CPP dissolution from bone was enhanced in patients with secondary hyperparathyroidism, ${ }^{29}$ suggesting a significant benefit of CD use in patients with controlled PTH (iPTH $\otimes 132 \mathrm{pg} / \mathrm{mL})(P=0.036)$ (Fig. 3). If $\mathrm{Pi}$ is controlled ( $\mathrm{Pi} \leqq 6 \mathrm{mg} / \mathrm{dL})$, PTH will also be suppressed, and the anti-calcification effect of CD use will be more effective $(P=0.008)$. Typically, patients on maintenance haemodialysis have chronic inflammation due to the uremic environment, low nutrition, the dialysis equipment used, and the use of $A D .{ }^{30}$ In vitro analysis showed that $C D$ significantly inhibited the induction of oxidative stress in the blood of these patients, as compared to AD. ${ }^{31}$ Thus, $C D$ is less inflammatory than AD and may inhibit the transition to a vicious cycle of atherosclerosis (i.e. malnutrition-inflammation-atherosclerosis syndrome). Therefore, if there is persistent inflammation in hemodialysis patients, AD may further induce inflammation, and CD may reduce inflammation. Subgroup analysis showed that CD was significantly more 
favorable than AD in inhibiting the progression of vascular calcification when CRP levels were $\geqq 0.1 \mathrm{mg} / \mathrm{dL}(P=$ 0.041). Under the conditions of low Ca levels and no CaCO3 use, the chelating effect of citric acid on Ca ions was more effective, and $\mathrm{CD}$ was thought to have a more anti-calcification effect than $\mathrm{AD}(P=0.044$ under $\mathrm{cCa}<9$ $\mathrm{mg} / \mathrm{dL}, P=0.036$ without $\mathrm{CaCO} 3$ use). $\mathrm{CD}$ had a significant anti-calcification effect compared to AD when the AoACS was $<19(\%)$. The reason for this is that it has been reported that when calcification is already highly advanced, treatment is unlikely to have an inhibitory effect on progression. ${ }^{32}$

Warfarin induces vascular calcification by inhibiting matrix Gla protein, an inhibitor of calcification in arteries, in both models of $\mathrm{CKD}^{33}$ and in clinical trials of patients on haemodialysis. ${ }^{34}$ Therefore, patients on warfarin were excluded from our study. Patients using bisphosphonates were also excluded as bisphosphonate use reportedly reduced the coronary artery calcification scores in patients on maintenance haemodialysis ${ }^{35}$ and inhibited rat aortic calcification by reducing bone-derived CPP. ${ }^{29}$

There are several limitations in the present study. First, we did not measure blood Mg levels. Administration of magnesium oxide $(\mathrm{MgO})$ significantly inhibited the progression of coronary artery calcification in patients with $\mathrm{CKD}^{36}$ and basic experiments in vascular smooth muscle cells showed that $\mathrm{Mg}$ dose-dependently inhibited calcification, ${ }^{37} \mathrm{Mg}$ citrate treatment reduced the carotid intima-media thickening in haemodialysis patients, ${ }^{38}$ and elevation of $\mathrm{Mg}$ concentration in the dialysate prolonged the T50. ${ }^{39}$ Thus, blood $\mathrm{Mg}$ levels and oral medications containing $\mathrm{Mg}$ are associated with vascular calcification and atherosclerosis in dialysis patients. Nevertheless, none of the patients in this study were receiving oral medications containing Mg. Second, blood bicarbonate and citrate levels may be associated with vascular calcification, but these were not measured in this study. Third, observational study is not of high quality as a research method, and the number of patients included in this study was small.

In conclusion, for patients on maintenance haemodialysis, $C D$ is more effective than $A D$ in inhibiting the progression of vascular calcification as assessed by $\triangle$ AoACS. Larger randomised controlled trials are warranted to validate the anti-atherosclerotic results obtained with the use of $C D$, and to elucidate the mechanism of this therapeutic effect.

\section{Methods}

\section{Study design and population}

This was a retrospective observational study. We used a 12-month observation period, from October 2017 to October 2018. Eligibility criteria were as follows: 1) having undergone maintenance haemodialysis at Joban Hospital (Fukushima, Japan); 2) patients who, upon introduction of dialysis treatment, have given written informed consent to save the remaining plasma collected for routine testing and subsequently use it for research; 3 ) those on continuous outpatient maintenance dialysis for 12 months; 4) those who had available data; 5) $\geq 18$ years of age; 6) no active cancer; and 7) those stable for at least 3 months after dialysis induction at baseline. Patients using warfarin or bisphosphonates and those with a baseline AoACS of $100 \%$ were excluded.

We have obtained written informed consent for renal biopsy from all patients, and clinical data were obtained from all recently recruited patients, who had the opportunity to opt-out from this study.

\section{Treatment interventions}


The dialysis centre had two floors; originally, all patients on maintenance haemodialysis were on AD. Patients on the 1st floor remained on $A D$, while patients on the 2nd floor were assigned to start CD from October 2017. AoACS was compared between two groups: one in which AD (Kindary 4E®; Fuso Pharmaceutical Co., LTD, Osaka, Japan) remained unchanged and the other in which $A D$ was changed to $C D$ (Carbostar®; Ajinomoto Pharmaceutical Co., LTD, Tokyo, Japan). All relevant investigators were blinded to the treatment groups.

\section{Composition of the dialysis solution}

According to their respective product descriptions, the composition of $A D$ is $140 \mathrm{mEq} / \mathrm{L}$ of sodium, $2 \mathrm{mEq} / \mathrm{L}$ potassium, $2.75 \mathrm{mEq} / \mathrm{L}$ calcium (Ca), $1 \mathrm{mEq} / \mathrm{L}$ magnesium $(\mathrm{Mg}), 112.25 \mathrm{mEq} / \mathrm{L}$ chloride, $8 \mathrm{mEq} / \mathrm{L}$ acetic acid, 0 $\mathrm{mEq} / \mathrm{L}$ citrate, $27.5 \mathrm{mEq} / \mathrm{L}$ bicarbonate, and $125 \mathrm{mg} / \mathrm{dL}$ glucose. The composition of the CD was the same as above, except for the following: $3 \mathrm{mEq} / \mathrm{L} \mathrm{Ca}, 111 \mathrm{mEq} / \mathrm{L}$ chloride, $0 \mathrm{mEq} / \mathrm{L}$ acetic acid, $2 \mathrm{mEq} / \mathrm{L}$ citrate, $35 \mathrm{mEq} / \mathrm{L}$ bicarbonate, and $150 \mathrm{mg} / \mathrm{dL}$ glucose (Supplementary Table).

\section{Comparison method and outcomes}

AoACS progression was defined as $\triangle$ AoACS (12-month AoACS - baseline [0-month] AoACS) $>0 \%$ over the 12 month observation period and was compared between the $A D$ and $C D$ groups. Thus, $\triangle A O A C S=0$ was interpreted as no AoACS progression during the 12-month observation period, and $\triangle \mathrm{AoACS}<0$ was interpreted as improvement in AoACS.

\section{Evaluation scale and evaluator}

Chest X-ray imaging was performed after dialysis, and the X-ray image was divided into 16 sections using the previously described method. ${ }^{2}$ The presence of one calcification was calculated as 1 point divided by 16 sections $\times$ $100(\%)=6.25(\%)$; thus, 1 point $=6.25 \%$. A clinical engineering technician at Joban Hospital performed the AoACS measurements and was available for consultations at the Department of Radiology at Tokyo Women's Medical University as needed.

\section{Sample collection}

In the non-fasting state, blood samples were taken at the beginning of the week, 2 days after the last dialysis, and were obtained before beginning the dialysis procedure. Isolated plasma samples were promptly stored at $-80^{\circ} \mathrm{C}$ until they were used in experiments. The baseline and follow-up clinical data, such as age, sex, diabetes mellitus (DM) as the primary disease of end-stage renal disease, dialysis vintage (number of years on dialysis), mean arterial blood pressure (MAP), body mass index (BMI), dry weight, and use of Ca-containing phosphate-binders, vitamin D, calcimimetics, renin-angiotensin system (RAS) inhibitors, dialysis modality (haemodialysis, online haemodiafiltration, intermittent infusion haemodiafiltration), $\mathrm{Kt} / \mathrm{V}$, haemoglobin ( $\mathrm{Hb}$ ), and erythropoietin-stimulating agents were determined. Biochemical tests, using a plasma sample assayed the following: inorganic phosphorus $(\mathrm{Pi}), \mathrm{Ca}, \mathrm{Ca} \times \mathrm{Pi}$ product, intact parathyroid hormone (iPTH), alkaline phosphatase (ALP), C-reactive protein (CRP), albumin (Alb), normalised protein catabolic rate (nPCR), low density lipoprotein cholesterol (LDL-c), high density lipoprotein cholesterol (HDL-c), triglycerides (TG), blood urea nitrogen (BUN), and creatinine (Cre) levels were obtained from the patients' medical records. Corrected $\mathrm{Ca}$ (cCa) was calculated when the blood Alb was $<4$, based on Payne's formula: $\mathrm{cCa}=$ blood $\mathrm{Ca}+4-\mathrm{Alb}$. For the calculation of $\mathrm{Kt} / \mathrm{V}$, the single-pool Kt/ $\mathrm{V}_{\text {urea }}$ was calculated using Daugirdas' formula: Kt/V = -Ln (Ct/CO-0.008t) + (4 - 3.5Ct/Co) $\times \Delta B W / D W,(C t:$ post-dialysis BUN, Co: predialysis BUN, t: dialysis time [h], $\triangle B W$ : weight loss during dialysis, DW: post-dialysis weight). MAP was calculated as (systolic blood pressure - diastolic blood pressure) / $3+$ diastolic blood pressure. The erythropoietin resistance index (ERI) was calculated as erythropoiesis stimulating agent dose / (post-dialysis weight $\times \mathrm{Hb}$ ) values. The 
conversion ratio was calculated as recombinant human erythropoietin (rHuEPO): darbepoetin a (DA): epoetin $\beta$ pegol (C. E. R. A.) = 200: 1: 1 .

\section{Ethics}

This study adhered to the tenets of the Declaration of Helsinki and was approved by the Medical Ethics Committee at the Joban Hospital, Iwaki-city, Fukushima, Japan (\# 5104). Since this was an observational study and no invasive procedures were performed, patient consent was obtained in an opt-out format for the use of residual plasma in regular practice.

\section{Statistical analyses}

Data were expressed as means \pm standard deviations if normally distributed; otherwise, they were reported as median and interquartile range (25-75 percentile) for non-normally distributed data. The baseline characteristics of the two groups were compared using analysis of variance as a parametric or a nonparametric test. Comparisons between proportions were made using chi-square tests. In case of two-group comparisons of normally distributed data, equal variance tests were performed for quantitative variables, by Student's $t$-test for equal variances, and Welch's $t$-test for unequal variances. For two-group comparisons of non-normally distributed data, Wilcoxon's signed-rank test was used for quantitative variables. The baseline characteristics of the two groups were subjected to univariate and multivariate logistic regression analyses to assess the impact of factors on AoACS progression. Odds ratios (ORs) were expressed with $95 \%$ confidence intervals (Cls). $P$-value $<0.05$ was considered statistically significant.

A subgroup analysis was used to examine the characteristics involved in the suppressive effect of CD on AoACS progression. As this was an observational study and prone to various confounders, we performed 1:1 propensity score matching to adjust for covariates and estimate causal association. We created a model that adjusted for all baseline characteristics (Table 4) as covariates, for the outcome of AoACS progression due to AD and CD treatment interventions. The model was used to perform propensity score matching. The analyses were performed with JMP version 15 (SAS Institute Inc., Cary, NC).

\section{Declarations}

\section{Acknowledgements:}

We are very grateful to Naganuma Toshiaki, a clinical engineer, for his contribution to this study.

\section{Authors' Contributions:}

N.H., K.A., Y.M., K.K., and T.M. designed the study, K.A. collected, analysed, interpreted the data, and wrote the draft of the manuscript. Y.M. and M.K. contributed to the measurement of CPP and FGF23 in the blood and the interpretation of the data. T.M., N.H., K.A., Y.M., K.K., M.S., Y.I., H.S., H.K., K.U., K.T., and K.N. contributed to the interpretation of the data and critically reviewed the manuscript. All authors have read and provided approval of the version of the manuscript to be submitted.

\section{Disclosure:}


All the authors declared no competing interests.

K.A. - None.

N.H. - None.

Y.M. - None.

M.S. - None.

Y.M. - None.

Y.I. - None.

K.K. - None.

H.S. - None.

K.U. - None.

H.K. - None.

K.T. - None.

M.K. - None.

K.N. - None.

T.M. - None.

\section{References}

1. Chronic Kidney Disease Prognosis Consortium. et al. Association of estimated glomerular filtration rate and albuminuria with all-cause and cardiovascular mortality in general population cohorts: a collaborative metaanalysis., 375, 2073-2081 https://doi.org/10.1016/S0140-6736(10)60674-5 (2010).

https://www.ncbi.nlm.nih.gov/pubmed/20483451

2. Ogawa, T. et al. Simple evaluation of aortic arch calcification by chest radiography in hemodialysis patients. Hemodial Int, 13, 301-306 https://doi.org/10.1111/j.1542-4758.2009.00366.x (2009). https://www.ncbi.nlm.nih.gov/pubmed/19486186

3. Ogawa, T. et al. Progression of aortic arch calcification and all-cause and cardiovascular mortality in chronic hemodialysis patients. Int. Urol. Nephrol, 42, 187-194 https://doi.org/10.1007/s11255-009-9574-5 (2010). https://www.ncbi.nlm.nih.gov/pubmed/19430924

4. Abdelmalek, J. A., Stark, P., Walther, C. P., Ix, J. H. \& Rifkin, D. E. Associations between coronary calcification on chest radiographs and mortality in hemodialysis patients. Am. J. Kidney Dis, 60, 990-997 https://doi.org/10.1053/j.ajkd.2012.06.018 (2012). https://www.ncbi.nlm.nih.gov/pubmed/22883135

5. Komatsu, M., Okazaki, M., Tsuchiya, K., Kawaguchi, H. \& Nitta, K. Aortic arch calcification predicts cardiovascular and all-cause mortality in maintenance hemodialysis patients. Kidney Blood Press. Res, 39, 658-667 https://doi.org/10.1159/000368476 (2014). https://www.ncbi.nlm.nih.gov/pubmed/25571879 
6. Noordzij, M. et al. Progression of aortic calcification is associated with disorders of mineral metabolism and mortality in chronic dialysis patients. Nephrol. Dial. Transplant, 26, 1662-1669 https://doi.org/10.1093/ndt/gfq582 (2011). https://www.ncbi.nlm.nih.gov/pubmed/20880929

7. Hamano, T. et al. Fetuin-mineral complex reflects extraosseous calcification stress in CKD. J. Am. Soc. Nephrol, 21, 1998-2007 (2010). 10.1681/ASN.2009090944https://www.ncbi.nlm.nih.gov/pubmed/20947626

8. Smith, E. R. et al. Phosphorylated fetuin-A-containing calciprotein particles are associated with aortic stiffness and a procalcific milieu in patients with pre-dialysis CKD. Nephrol. Dial. Transplant, 27, 1957-1966 https://doi.org/10.1093/ndt/gfr609 (2012). https://www.ncbi.nIm.nih.gov/pubmed/22105144

9. Heiss, A. et al. Structural basis of calcification inhibition by alpha 2-HS glycoprotein/fetuin-A. Formation of colloidal calciprotein particles. J. Biol. Chem, 278, 13333-13341 https://doi.org/10.1074/jbc.M210868200 (2003). https://www.ncbi.nlm.nih.gov/pubmed/12556469

10. Schafer, C. et al. The serum protein alpha 2-Heremans-Schmid glycoprotein/fetuin-A is a systemically acting inhibitor of ectopic calcification. J. Clin. Invest, 112, 357-366 https://doi.org/10.1172/JCl17202 (2003). https://www.ncbi.nIm.nih.gov/pubmed/12897203

11. Miura, Y. et al. Identification and quantification of plasma calciprotein particles with distinct physical properties in patients with chronic kidney disease. sci. rep., 1256. Sci Rep, 8, 1256 https://doi.org/10.1038/s41598-01819677-4 (2018). https://www.ncbi.nlm.nih.gov/pubmed/29352150

12. Akiyama, K. I. et al. Calciprotein particles regulate fibroblast growth factor-23 expression in osteoblasts. Kidney Int, 97, 702-712 https://doi.org/10.1016/j.kint.2019.10.019 (2020). https://www.ncbi.nlm.nih.gov/pubmed/32001068

13. Herrmann, M. et al. Clearance of fetuin-A-containing calciprotein particles is mediated by scavenger receptor-A. Circ. Res, 111, 575-584 https://doi.org/10.1161/CIRCRESAHA.111.261479 (2012). https://www.ncbi.nlm.nih.gov/pubmed/22753077

14. Aghagolzadeh, P. et al. Calcification of vascular smooth muscle cells is induced by secondary calciprotein particles and enhanced by tumor necrosis factor-a. Atherosclerosis, 251, 404-414 https://doi.org/10.1016/j.atherosclerosis.2016.05.044 (2016). https://www.ncbi.nlm.nih.gov/pubmed/27289275

15. Nakazato, J. et al. Association of calciprotein particles measured by a new method with coronary artery plaque in patients with coronary artery plaque in patients with coronary artery disease: A cross sectional study. J. Cardiol, 74, 428-435 https://doi.org/10.1016/j.jjcc.2019.04.008 (2019). https://www.ncbi.nlm.nih.gov/pubmed/31101573

16. Scialla, J. J. et al. Fibroblast growth factor 23 is not associated with and does not induce arterial calcification. Kidney Int, 83, 1159-1168 https://doi.org/10.1038/ki.2013.3 (2013). https://www.ncbi.nlm.nih.gov/pubmed/23389416

17. Yamada, S. \& Giachelli, C. M. Vascular calcification in CKD-MBD: Roles for phosphate, FGF23, and Klotho. Bone, 100, 87-93 https://doi.org/10.1016/j.bone.2016.11.012 (2017). https://www.ncbi.nlm.nih.gov/pubmed/27847254

18. Akiyama, K., Kimura, T. \& Shiizaki, K. Biological and clinical effects of calciprotein particles on chronic kidney disease-mineral and bone disorder. Int. J. Endocrinol. 2018, 5282389 (2018). 10.1155/2018/5282389

19. Couchoud, C. et al. Impact of the dialysate acid component on haemodialysis mortality rates. Nephrol. Dial. Transplant, 35, 1244-1249 https://doi.org/10.1093/ndt/gfaa168 (2020). https://www.ncbi.nlm.nih.gov/pubmed/32777080 
20. Gutiérrez, O. M. et al. Fibroblast growth factor 23 and mortality among patients undergoing hemodialysis. $N$. Engl. J. Med, 359, 584-592 https://doi.org/10.1056/NEJMoa0706130 (2008).

https://www.ncbi.nlm.nih.gov/pubmed/18687639

21. Faul, C. et al. FGF23 induces left ventricular hypertrophy. J. Clin. Invest, 121, 4393-4408 https://doi.org/10.1172/JCl46122 (2011). https://www.ncbi.nlm.nih.gov/pubmed/21985788

22. Lorenz, G. et al. Acetate-free, citrate-acidified bicarbonate dialysis improves serum calcification propensity - A preliminary study. Nephrol. Dial. Transplant, 33, 2043-2051 https://doi.org/10.1093/ndt/gfy134 (2018). https://www.ncbi.nlm.nih.gov/pubmed/29860419

23. Ter Meulen, K. J. et al. Citric-acid dialysate improves the calcification propensity of hemodialysis patients: A multicenter prospective randomized cross- over trial. PLOS ONE, 14, e0225824 https://doi.org/10.1371/journal.pone.0225824 (2019). https://www.ncbi.nlm.nih.gov/pubmed/31805104

24. Villa-Bellosta, R., Hernández-Martínez, E., Mérida-Herrero, E. \& González-Parra, E. Impact of acetate- or citrateacidified bicarbonate dialysate on ex vivo aorta wall calcification. sci. rep., 11374. Sci Rep, 9, 11374 https://doi.org/10.1038/s41598-019-47934-7 (2019). https://www.ncbi.nlm.nih.gov/pubmed/31388059

25. Schmitz, M. et al. Effects of citrate dialysate in chronic dialysis: A multicentre randomized crossover study. Nephrol. Dial. Transplant, 31, 1327-1334 https://doi.org/10.1093/ndt/gfv347 (2016).

https://www.ncbi.nlm.nih.gov/pubmed/26442902

26. Masuda, A. et al. Effects of acetate-free citrate dialysate on glycoxidation and lipid peroxidation products in hemodialysis patients. Nephron Extra, 2, 256-268 https://doi.org/10.1159/000342258 (2012). https://www.ncbi.nlm.nih.gov/pubmed/23599704

27. Taki, K., Takayama, F., Tsuruta, Y. \& Niwa, T. Oxidative stress, advanced glycation end product, and coronary artery calcification in hemodialysis patients. Kidney Int, 70, 218-224 https://doi.org/10.1038/sj.ki.5000330 (2006). https://www.ncbi.nlm.nih.gov/pubmed/16723988

28. Yamamoto, Y. et al. Possible involvement of increased glycoxidation and lipid peroxidation of elastin in atherogenesis in haemodialysis patients. Nephrol. Dial. Transplant, 17, 630-636 https://doi.org/10.1093/ndt/17.4.630 (2002). https://www.ncbi.nlm.nih.gov/pubmed/11917057

29. Matsui, I. et al. Fully phosphorylated fetuin-A forms a mineral complex in the serum of rats with adenineinduced renal failure. Kidney Int, 75, 915-928 https://doi.org/10.1038/ki.2008.700 (2009). https://www.ncbi.nlm.nih.gov/pubmed/19190677

30. Amore, A. \& Coppo, R. Immunological basis of inflammation in dialysis. Nephrol. Dial. Transplant, 17 Suppl 8 , 16-24 https://doi.org/10.1093/ndt/17.suppl_8.16 (2002). https://www.ncbi.nlm.nih.gov/pubmed/12147772

31. Pérez-García, R. et al. Citrate dialysate does not induce oxidative stress or inflammation in vitro as compared to acetate dialysate. Nefrologia, 37, 630-637 https://doi.org/10.1016/j.nefro.2017.03.024 (2017). https://www.ncbi.nlm.nih.gov/pubmed/2912221131

32. Wada, K. \& Wada, Y. Evaluation of aortic calcification with lanthanum carbonate vs. calcium-based phosphate binders in maintenance hemodialysis patients with type 2 diabetes mellitus: an open-label randomized controlled trial. Ther. Apher. Dial, 18, 353-360 https://doi.org/10.1111/1744-9987.12153 (2014). https://www.ncbi.nlm.nih.gov/pubmed/24417760

33. McCabe, K. M. et al. Dietary vitamin K and therapeutic warfarin alter the susceptibility to vascular calcification in experimental chronic kidney disease. Kidney Int, 83, 835-844 https://doi.org/10.1038/ki.2012.477 (2013). https://www.ncbi.nlm.nih.gov/pubmed/23344475

Page 20/23 
34. Fusaro, M. et al. Prevalence of vertebral fractures, vascular calcifications, and mortality in warfarin treated hemodialysis patients. Curr. Vasc. Pharmacol, 13, 248-258 https://doi.org/10.2174/15701611113119990146 (2015). https://www.ncbi.nlm.nih.gov/pubmed/23927679

35. Nitta, K. et al. Effects of cyclic intermittent etidronate therapy on coronary artery calcification in patients receiving long-term hemodialysis. Am. J. Kidney Dis, 44, 680-688 https://doi.org/10.1016/S02726386(04)00937-0 (2004). https://www.ncbi.nlm.nih.gov/pubmed/15384019

36. Sakaguchi, Y. et al. A randomized trial of magnesium oxide and oral Carbon Adsorbent for Coronary artery Calcification in predialysis CKD. J. Am. Soc. Nephrol, 30, 1073-1085 https://doi.org/10.1681/ASN.2018111150 (2019). https://www.ncbi.nlm.nih.gov/pubmed/31036759

37. Kircelli, F. et al. Magnesium reduces calcification in bovine vascular smooth muscle cells in a dose-dependent manner. Nephrol. Dial. Transplant, 27, 514-521 https://doi.org/10.1093/ndt/gfr321 (2012). https://www.ncbi.nlm.nih.gov/pubmed/21750166

38. Turgut, F. et al. Magnesium supplementation helps to improve carotid intima media thickness in patients on hemodialysis. Int. Urol. Nephrol, 40, 1075-1082 https://doi.org/10.1007/s11255-008-9410-3 (2008). https://www.ncbi.nlm.nih.gov/pubmed/18568412

39. Bressendorff, I., Hansen, D., Schou, M., Pasch, A. \& Brandi, L. The effect of increasing dialysate magnesium on serum calcification propensity in subjects with end stage kidney disease: a randomized, controlled clinical trial. Clin. J. Am. Soc. Nephrol, 13, 1373-1380 https://doi.org/10.2215/CJN.13921217 (2018).

https://www.ncbi.nlm.nih.gov/pubmed/30131425

\section{Figures}

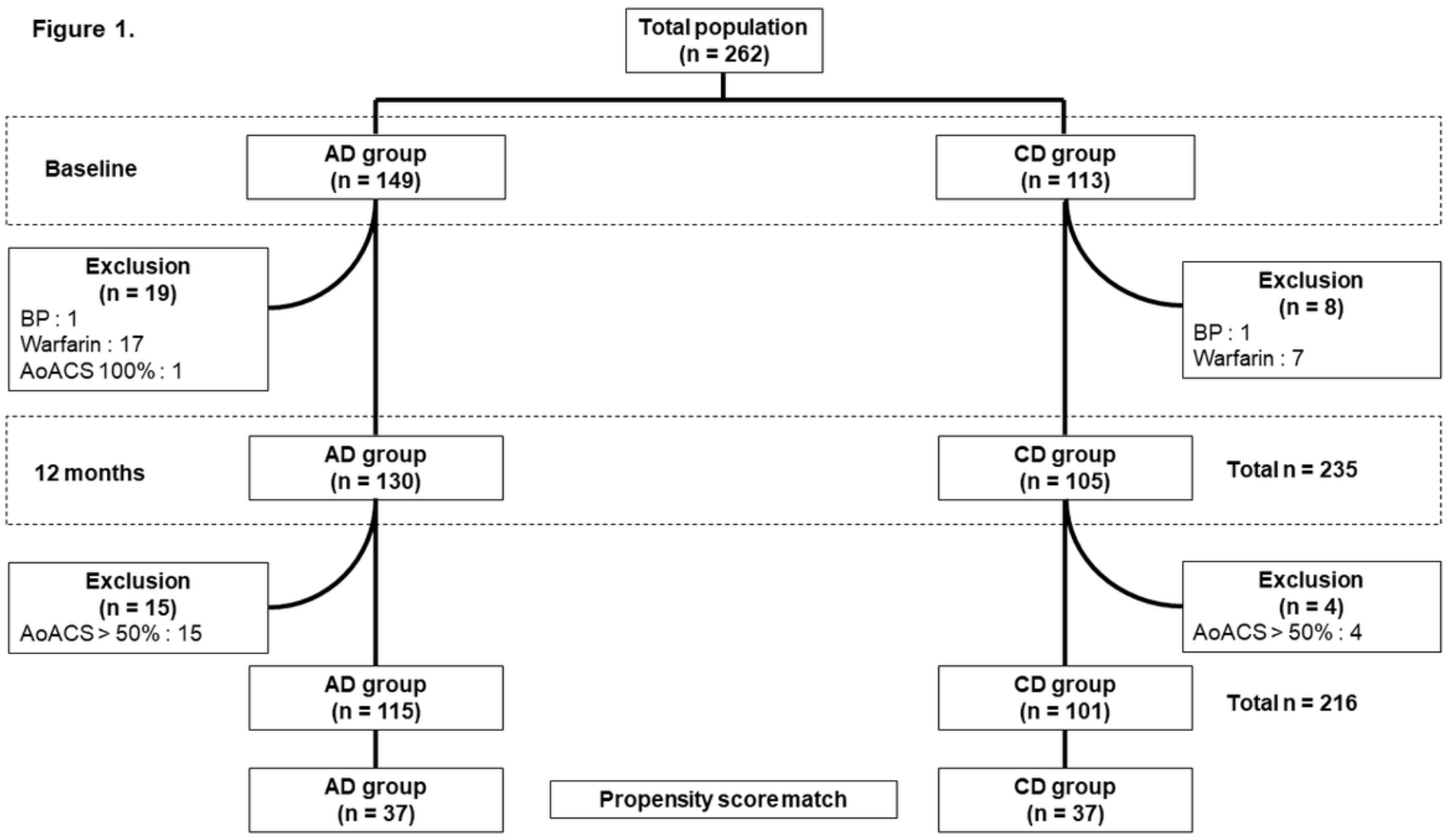

Figure 1 
Flow diagram of study participants. AD, acetate acid-based bicarbonate dialysate; $C D$, citric acid-based bicarbonate dialysate; HD, haemodialysis; O-HDF, online hemodiafiltration; I-HDF, intermittent infusion hemodiafiltration; PSM, propensity score matching.

Figure 2.

a)

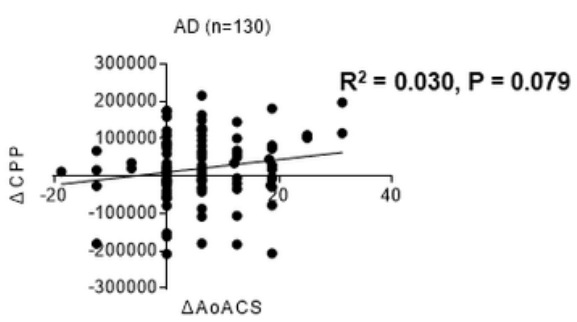

c)

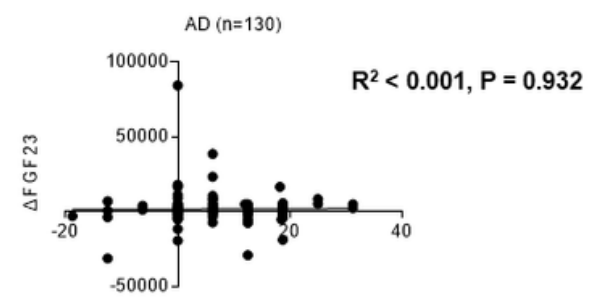

$\triangle A O A C S$

e)

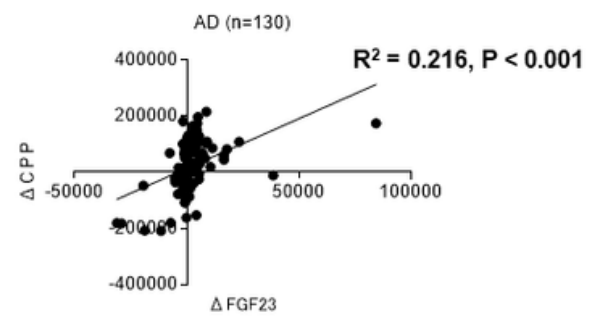

b)

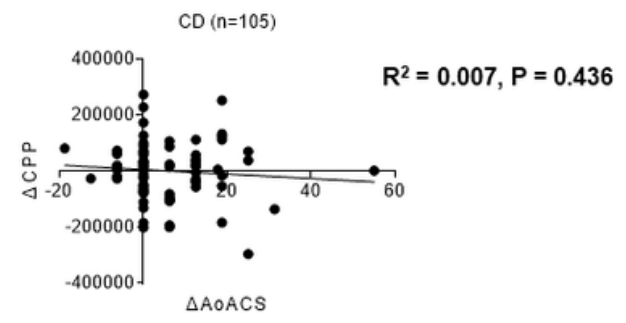

d)

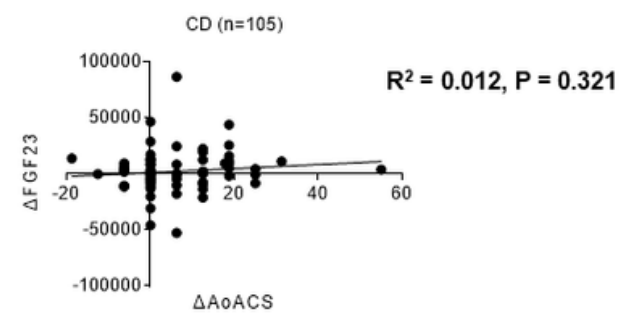

f)

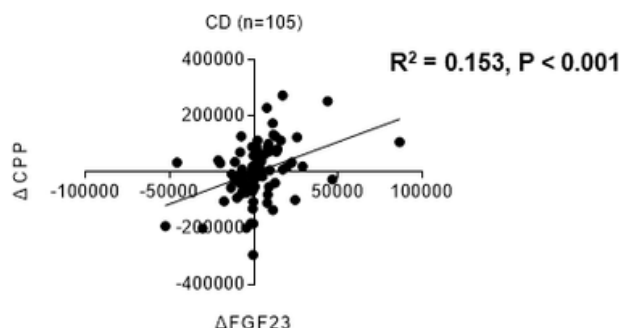

\section{Figure 2}

Relationship between blood CPP and AoACS and blood FGF23 $(n=235)$. a) Correlation of $\triangle$ CPP and $\triangle$ AoACS in the AD group. b) Correlation of $\triangle \mathrm{CPP}$ and $\triangle \mathrm{AoACS}$ in the CD group. c) Correlation of $\triangle F G F 23$ and $\triangle \mathrm{Ao} A C S$ in the $A D$ group. d) Correlation of $\triangle \mathrm{FGF} 23$ and $\triangle \mathrm{AoACS}$ in the CD group. e) Correlation of $\triangle \mathrm{FGF} 23$ and $\triangle \mathrm{CPP}$ in the AD group. f) Correlation of $\triangle F G F 23$ and $\triangle \mathrm{CPP}$ in the CD group. CPP, calciprotein particle; AoACS, aortic arch calcification score; $A D$, acid-based bicarbonate dialysate; $C D$, citric acid-based bicarbonate dialysate; FGF23, fibroblast factor-23. Note: Statistically significant P-values are in bold. 
Figure 3.

a)

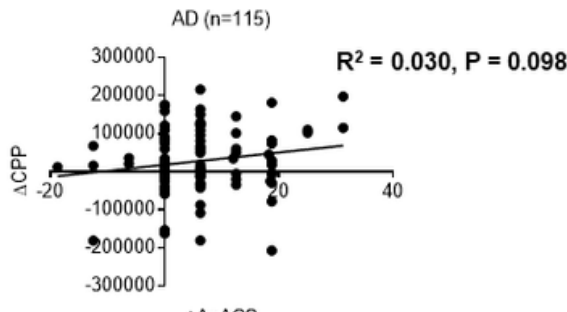

c)

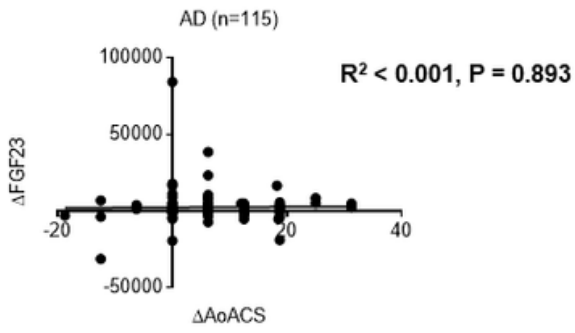

e)

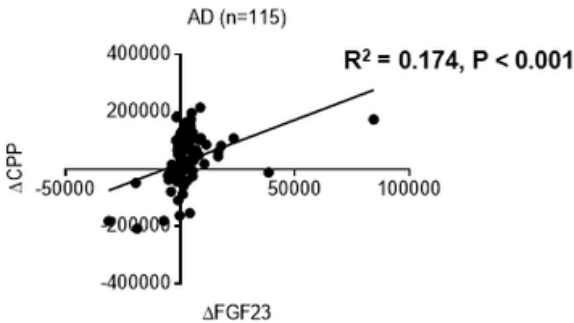

b)

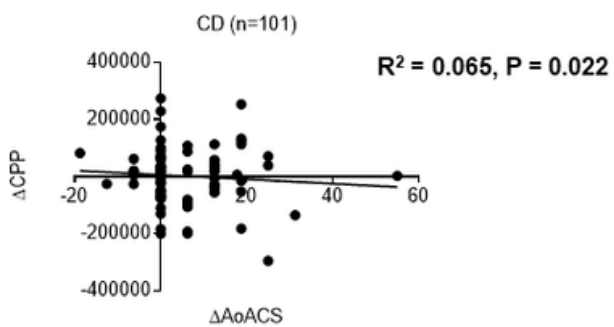

d)

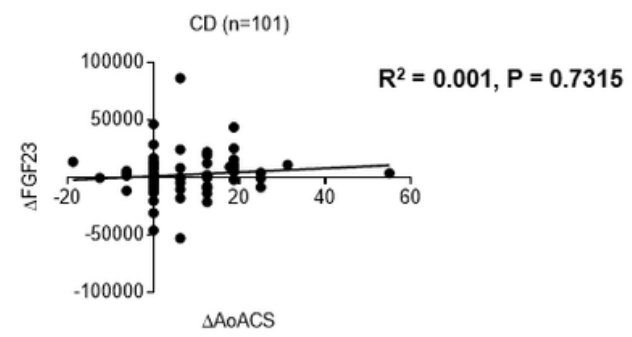

f)

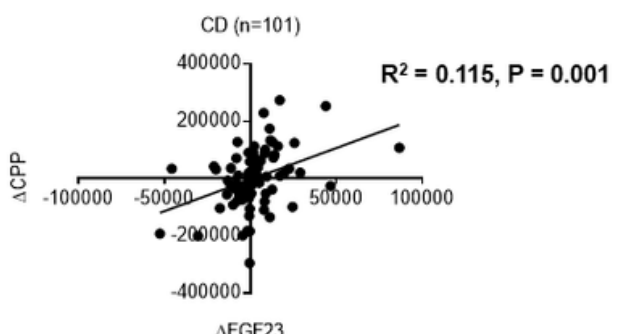

Figure 3

Relationship between blood CPP and AoACS and blood FGF23 $(n=216)$. a) Correlation of $\triangle$ CPP and $\triangle$ AoACS in the AD group. b) Correlation of $\triangle \mathrm{CPP}$ and $\triangle \mathrm{AoACS}$ in the CD group. c) Correlation of $\triangle F G F 23$ and $\triangle \mathrm{AoACS}$ in the $A D$ group. d) Correlation of $\triangle F G F 23$ and $\triangle$ AoACS in the CD group. e) Correlation of $\triangle F G F 23$ and $\triangle C P P$ in the AD group. f) Correlation of $\triangle F G F 23$ and $\triangle \mathrm{CPP}$ in the CD group. CPP, calciprotein particle; AoACS, aortic arch calcification score; $A D$, acid-based bicarbonate dialysate; $C D$, citric acid-based bicarbonate dialysate; FGF23, fibroblast factor-23. Note: Statistically significant P-values are in bold.

\section{Supplementary Files}

This is a list of supplementary files associated with this preprint. Click to download.

- SciRepSuppleFigureTables.pptx 